\title{
Head pediculosis in schoolchildren in the eastern region of the European Union
}

\author{
Katarzyna Bartosik', Alicja Buczek', Zbigniew Zając' ${ }^{1}$, Joanna Kulisz'1 \\ ${ }^{1}$ Chair and Department of Biology and Parasitology, Medical University of Lublin, Poland
}

Bartosik K, Buczek A, Zając Z, Kulisz J. Head pediculosis in schoolchildren in the eastern region of the European Union. Ann Agric Environ Med. 2015; 22(4): 599-603. doi: 10.5604/12321966.1185760

\begin{abstract}
Objective. The aim of the study was to investigate the prevalence of head pediculosis among children from state primary schools in the villages and towns in eastern Poland, one of the poorest regions of the European Union.

Materials and methods. The study was conducted in 2009-2012 in 30 rural and urban State schools. Current and previous results (1996-2000) of examinations performed in the study area were compared. The impact of socioeconomic factors on the prevalence of head pediculosis in eastern Poland in the period of 16 years was analysed.

Results. Pediculosis was diagnosed in $2.01 \%$ of the schoolchildren, more frequently in pupils from rural (3.52\%) than urban $(0.98 \%)$ schools. Lice infestation was higher in girls $(59.52 \%)$ than in boys $(40.48 \%)$. The risk of pediculosis in children increased in schools that did not employ a nurse (mean 5.07\%) and decreased when a part-time (mean 2.96\%) or full-time nurse (mean 1.01\%) was employed. The incidence of pediculosis doubled despite the improvement in the socioeconomic status of the population observed within the last 16 years.

Conclusion. The results indicate that personal hygiene behaviour may be of key importance in determining the spread of the disease.
\end{abstract}

\section{Key words}

pediculosis, Pediculus humanus capitis, health services, socioeconomic factors

\section{INTRODUCTION}

Head pediculosis is the most common parasitic arthropodborne disease worldwide. The human louse Pediculus humanus capitis (Anoplura: Pedicullidae) is its etiological agent. The disease most frequently affects children and teenagers [1]. It is manifested by itching of the scalp and appearance of inflammatory papules at the site of the louse bite within several hours or a few days after infestation. Scratches on the skin may be infected by bacteria. Serouspurulent discharge released from wounds solidifies on the skin surface and forms scabs. It can also glue the hair together, resulting in formation of a plica. Lice infestation can cause cervical lymphadenopathy and conjunctivitis [2], as well as allergic reactions within the nasal cavity manifested by nasal obstruction and rhinorhea [3].

Epidemiological data reveal considerable variability in the incidence of head pediculosis worldwide. A high prevalence of Pediculus humanus capitis is reported from countries differing in the level of economic and cultural development [1], which suggests a necessity to monitor the spread of pediculosis in different environments, and to determine the factors contributing to the incidence of the disease. The presented study thefore investigates the occurrence of pediculosis among the pupils of State schools in the Lublin region, situated along the Polish-Ukrainian border, the most easterly part of the European Union. Analysis of factors promoting the spread of the disease in the study area was also performed, based on more than 16 years of own research.

Address for correspondence: Katarzyna Bartosik Chair and Department of Biology and Parasitology, Medical University of Lublin, Radziwiłłowska 11, 20-080 Lublin, Poland

E-mail: alicja.buczek@umlub.pl

Received: 09 January 2014; accepted: 23 April 2014

\section{MATERIALS AND METHOD}

The study was conducted between 2009-2012 in 30 State schools located in an area of $25,155 \mathrm{~km}^{2}$ (eastern Poland, $51^{\circ} 15^{\prime} \mathrm{N}$ ), in which a similar study was carried out in $1996-$ 2000 [4]. 25 of the schools are situated in rural areas with a population ranging from $100-7,200$ inhabitants. 16 schools in the rural areas are located in villages with fewer than 500 residents and 8 schools in places with a population of $500-1,000.5$ schools are located in towns and cities with a population ranging between 5,200-348,000 inhabitants; 3 of these schools are situated in towns with $\leq 21,000$ residents and 2 with $\geq 67,000$ people. In total, 17,141 schoolchildren aged $7-13$ were examined, including 12,139 from the countryside and 5,002 from towns and cities. In the individual years of the study and throughout the study period, the incidence of pediculosis was determined according to the gender and in groups of rural schools with fewer than 180 pupils (18-179) and with 180-405 students, and in urban schools comprising $200-280$ and $300-400$ pupils. Additionally, information about school hygiene care, education of children, and cooperation of school staff with parents was collected in each of the schools. The Central Statistical Office provided data on the socioeconomic status of the population from the study area and in Poland (the level of education and unemployment in the respective counties, length of the water supply and sewerage networks in the study area) [5]. Based on the data, the area was analysed in terms of the existence of the following:

1) relationship between pediculosis incidence and access to permanent, temporary, or no school hygiene care (full-time nurse, part-time nurse, or no nurse employed at school);

2) relationship between pediculosis incidence and the number of pupils at school;

3) relationship between pediculosis incidence and the socioeconomic status of the population, e.g. unemployment 
rate, income per capita, education of the inhabitants, and length of the water supply and sewerage networks.

Statistical analysis. Analysis of the results was performed using statistical package PQStat ver. 1.4.2.324. The proportions of pediculosis cases in children in relation to the location of the school (village, town) and to the number of pupils in the school were compared using the MannWhitney $\mathrm{U}$ test. The Kruskal-Wallis $\mathrm{H}$ test was used for determination of the correlation between the number of pediculosis cases and access to nurse care. The relationship between the proportion of head pediculosis cases in children and the income and unemployment rate in the study area was analysed by estimation of Spearman's rank correlation coefficients. Probability was considered significant at $\mathrm{p}<0.05$ and highly significant at $\mathrm{p}<0.01$.

\section{RESULTS}

$2.01 \%$ of the 17,141 schoolchildren examined in the Lublin macroregion were infested by Pediculus humanus capitis. The incidence of head pediculosis was statistically significantly higher (Mann-Whitney $U$ test, $\mathrm{p}=0.0159$ ) in the rural than urban schools and reached $3.52 \%$ and $0.98 \%$ of the children, respectively. Both in the rural and urban schools, the proportion of infested pupils exhibited wide-range fluctuations during the individual study years and over the entire study period (Tab. 1). Analyses of each year separately revealed a statistically significant difference between the number pediculosis-affected children from the rural and urban schools only in 2010 ( $\mathrm{p}=0.0358)$, but in each study year, the prevalence of the disease was higher in the rural than urban schools (Tab. 1).
In rural schools comprising from 180-405 pupils, the proportion of lice-infested children ranged from $0 \%-5.0 \%$ in the individual years, and from $0.29 \%-4.0 \%$ in all schools throughout the observation period (mean $1.58 \pm 1.37 \%$ ). The prevalence of pediculosis was higher in rural schools with a lower number of students (18-179); the proportion of infested children ranged from $0 \%-20.0 \%$ in the individual study years, and from $0 \%-11.11 \%$ over the 4 -year observation period (mean $4.43 \pm 3.83 \%$ ). The Mann-Whitney U statistical test $(p=0.0707)$ did not show a significant difference in the prevalence of pediculosis in both groups of the rural schools, but the test probability was close to the assumed threshold value. It is noteworthy that a similar level of Pediculus humanus capitis infestation prevailed in the examined environments in the individual study years. The biggest number of infestations (8-10\%) was reported from schools attended by children from orphanages and single-parent homes. Each year, a high prevalence of head pediculosis (10-20\%) was reported in children returning from holidays to some small schools comprising 27-60 pupils.

In urban schools attended by the lower (200-280) and higher (300-400) number of pupils, the proportion of children infested by Pediculus humanus capitis was similar, both in the individual study years and over the entire study period (mean $0.79 \pm 0.40 \%$ and $1.06 \pm 0.56 \%$, respectively) (Tab. 1). This was also confirmed by the statistical analysis (Mann-Whitney $U$ test, $\mathrm{p}=0.4874$ ). In both these groups of schools, pediculosis was diagnosed in $0-1.50 \%$ of children in the individual years and persisted at a level of $0.5 \%-1.17 \%$ throughout the study period.

Irrespective of the locality of the school and number of pupils, the proportion of pediculosis-affected girls (60\%) was higher than that of boys (40\%). In the rural schools, the number of girls accounted for $45.83 \%-69.70 \%$ of the infested

Table 1. Prevalence of pediculosis in rural and urban schools in Lublin Province (Poland) 2009-2012

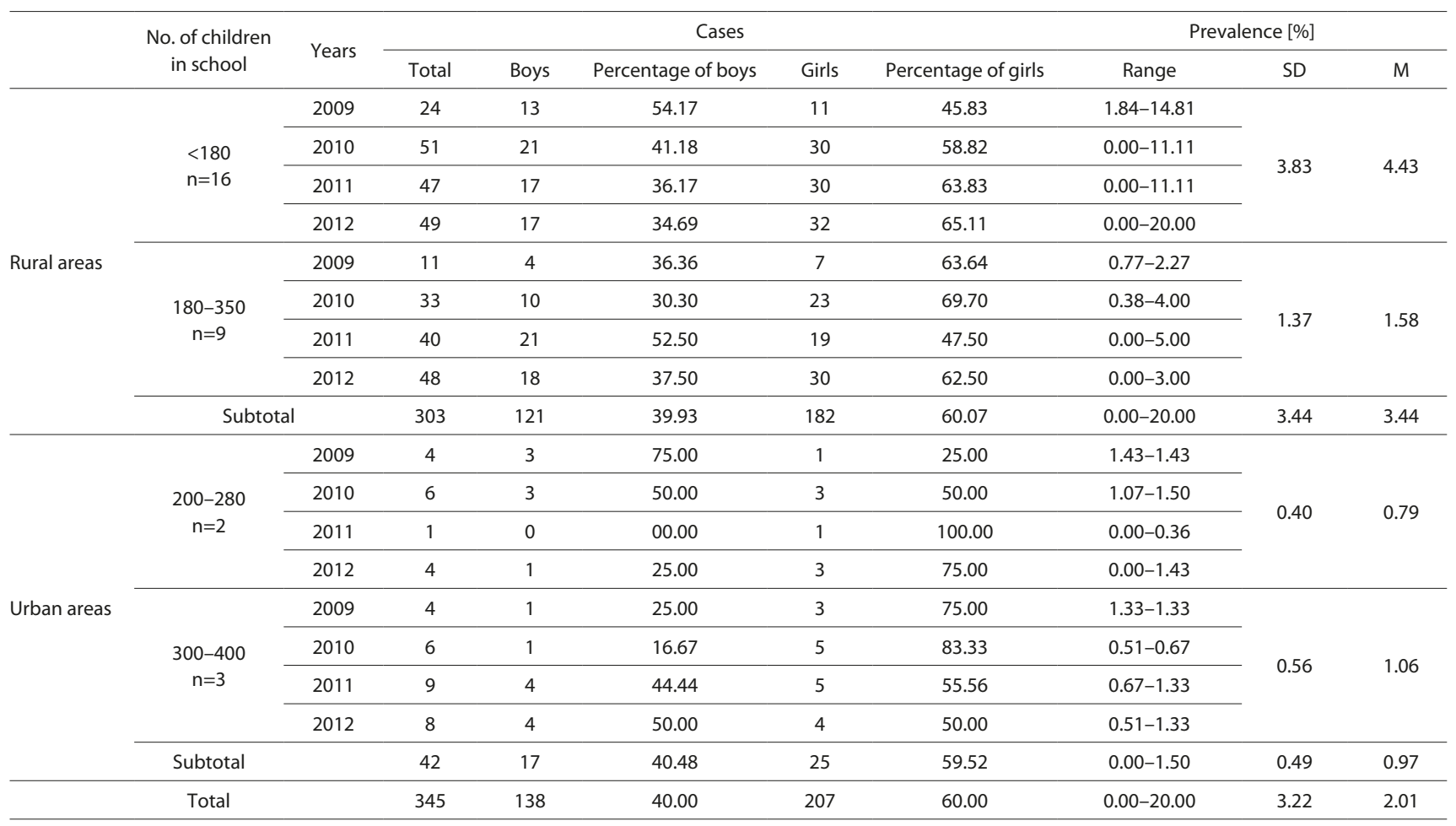

$\mathrm{n}=$ number of investigated schools; SD - standard deviation; $\mathrm{M}-$ mean 
Table 2. Prevalence of pediculosis in the study area in relation to access to nurse care at school

\begin{tabular}{lccc}
\hline & \multicolumn{3}{c}{ Prevalence (\%) } \\
\hline Presence of a nurse at school & Range & M & SD \\
\hline+ & $0.29-2.96$ & 1.01 & 0.42 \\
\hline$+/-$ & $0.00-10.77$ & 2.96 & 3.14 \\
\hline- & $0.00-20.00$ & 5.07 & 4.21 \\
\hline
\end{tabular}

+ full-time school nurse; +/- part-time school nurse; - lack of school nurse; SD- standard deviation, M- mean

children in the different study years. Larger disparities in the incidence of infection by the parasite in both genders were found in the urban schools, where the proportion of infested girls ranged from $25 \%$ to as much as $100 \%$.

The highest proportion of pediculosis (mean 5.07\%) was found in rural schools that did not employ a nurse (Tab. 2). A lower number of children were infested (mean 2.96\%) when children's heads were periodically checked by parttime nurses visiting the schools every month. The lowest proportion of pupils infested by Pediculus humanus capitis (1.01\%) was reported from schools with full-time nurses. However, the statistical tests did not reveal a significant correlation (Kruskal-Wallis test, $\mathrm{p}=0.0760$ ) between the number of pediculosis cases and access to nurse care, although the test probability was close to the assumed threshold value. This implies an increased risk of pediculosis in schools with no nursing care and the lowest risk in schools that employ a full-time nurse (Tab. 2).

In 7 schools $(23.33 \%)$ in which $2.08 \%-11.11 \%$ of pupils were infested by head lice, educational programmes were introduced in order to inform the parents and children about the epidemiology and treatment of pediculosis. In 8 other schools $(26.66 \%)$ where pediculosis prevalence reached $0.44 \%$ $-4.0 \%$, parents reported the need for cooperation in this field.

In the presented study, no significant $(p>0.05)$ correlations were found between the proportion of pediculosis infestations in children and the income per capita $(\mathrm{r}=-0.1213)$ and unemployment rate $(\mathrm{r}=0.1542)$ in the respective study region (Tab. 3).

Table 3. Pediculosis incidence and socioeconomic status of the population of the study area in 2011

\begin{tabular}{lccc}
\hline District & Prevalence (\%) & $\begin{array}{c}\text { District per capita } \\
\text { income (PLN) }\end{array}$ & Unemployment (\%) \\
\hline Lublin (city) & 0.50 & 1100 & 9.4 \\
\hline Chelm (city) & 1.07 & 780 & 16.5 \\
\hline Lublin & 0.69 & 1100 & 11.2 \\
\hline Chełm & 1.74 & 780 & 18.1 \\
\hline Lubartów & 5.17 & 880 & 16.3 \\
\hline Leczna & 3.44 & 810 & 10.1 \\
\hline Opole Lubelskie & 1.07 & 900 & 16.1 \\
\hline Wlodawa & 1.29 & 1550 & 22.8 \\
\hline Zamosc & 2.45 & 500 & 14.4 \\
\hline Losice & 2.63 & $1000-1199$ & 12.8 \\
\hline Garwolin & 6.00 & $800-999$ & 15.4 \\
\hline
\end{tabular}

PLN - New Polish Zloty (Polish currency since 1994)

\section{DISCUSSION}

The prevalence of infestation with Pediculus humanus capitis in children in the Lublin macroregion corresponds to the range reported from other European countries over the last 20 years, i.e. from $0.48 \%$ to ca. $10 \%[6,7,8]$. During the same period, a high prevalence of head pediculosis was reported in some environments in Asia (85\%) [9], South America (81.5\%) [10], and Africa (64.1\%) [11]. The literature provides scarce data from long-term monitoring of the prevalence of Pediculus humanus capitis invasions in the same environments, which makes it impossible to assess changes in the dynamics of infestation in children and determine the effect of factors contributing to the spread of the parasite in a long-term scale. Most epidemiological studies were carried out primarily in South America $[12,13]$ and Asia.

Table 4. Pediculosis in children in Poland based on literature data 1979-2008

\begin{tabular}{lcclc}
\hline Area & Years & Infestation & \multicolumn{1}{c}{ Type of institution } & Source \\
\hline $\begin{array}{l}\text { Gdansk } \\
\text { Province }\end{array}$ & 1979 & $\begin{array}{c}\text { autumn }-1.89 \% \\
\text { spring }-0.76 \%\end{array}$ & $\begin{array}{l}\text { kindergartens, primary } \\
\text { schools, orphanages, } \\
\text { detention centres }\end{array}$ & {$[25]$} \\
\hline $\begin{array}{l}\text { Gdansk } \\
\text { Province }\end{array}$ & $1990-1992$ & $3.20 \%$ & $\begin{array}{l}\text { kindergartens, primary } \\
\text { schools }\end{array}$ & {$[24]$} \\
\hline Wrocław & $1990-1997$ & $0.62 \%$ & $\begin{array}{l}\text { kindergartens, primary } \\
\text { schools, detention centres }\end{array}$ & {$[21]$} \\
\hline $\begin{array}{l}\text { Lublin } \\
\text { Province }\end{array}$ & $1996-2000$ & $1.6 \%$ & urban primary schools & {$[4]$} \\
\hline Warsaw & $2007-2008$ & $12.43-20.27 \%$ & children's homes & {$[22]$} \\
\hline
\end{tabular}

The current study shows that the incidence of infestation of children in rural and urban schools in eastern Poland has doubled, in comparison with the previous epidemiological study conducted in the same area in 1996-2000 [4], in which the values of $1.59 \%$ and $0.48 \%$ were reported for rural and urban schools, respectively. Previous studies conducted worldwide have indicated that the factors promoting Pediculus humanus capitis infestations are diverse and often controversial.

The correlation between the number of pediculosis cases and education of the population reported by some authors [7] was not confirmed by the presented findings, as during the 16-year observations in the Lublin macroregion the level of education of its inhabitants, and rural residents in particular, increased considerably (Tab. 5).

In comparison with the beginning of the century, in 20092011, the length of the water supply and sewerage network and the number of new sewer connections increased in the

Table 5. Changes in public education level in rural and urban areas during 10 years*

\begin{tabular}{lcccc}
\hline \multirow{2}{*}{ Type of education } & \multicolumn{2}{c}{ Urban areas } & \multicolumn{2}{c}{ Rural areas } \\
\cline { 2 - 5 } & 2002 & 2011 & 2002 & 2011 \\
\hline University education & $12.0 \%$ & $21.3 \%$ & $4.0 \%$ & $9.9 \%$ \\
\hline College & $39.0 \%$ & $35.2 \%$ & $22.5 \%$ & $25.5 \%$ \\
\hline Occupational education & $20.5 \%$ & $19.0 \%$ & $29.5 \%$ & $26.6 \%$ \\
\hline Secondary education & $21.5 \%$ & $17.9 \%$ & $39.0 \%$ & $31.6 \%$ \\
\hline Primary education & $1.0 \%$ & $0.9 \%$ & $5.0 \%$ & $2.1 \%$ \\
\hline
\end{tabular}

* data do not contain undeclared education 
Table 6. Changes in water supply and sanitation network in the study area $2000-2011$

\begin{tabular}{lcccc}
\hline & 2000 & 2005 & 2010 & 2011 \\
\hline Water supplies (km) & & & & \\
\hline Urban & 2195,2 & 2421,4 & 2625 & 2644 \\
\hline Rural & 12618,5 & 15063,3 & 16777,8 & 17212,4 \\
\hline Sanitation system (km) & & & & \\
\hline Urban & 1621,1 & 1936,1 & 2209,8 & 2260,1 \\
\hline Rural & 759,3 & 1430,3 & 2222,3 & 2595,5 \\
\hline Sewer connections (thousand) & & & & \\
\hline Urban & 68,5 & 80,4 & 86,1 & 86,7 \\
\hline Rural & 196,6 & 233,3 & 258,3 & 263,8 \\
\hline
\end{tabular}

urban and rural areas of the Lublin macroregion, which resulted in the raising of the living standards (Tab. 6). The improvement of sanitation infrastructure was particularly pronounced in the rural areas; nevertheless, the region is still regarded as one of the poorest regions in Poland and the European Union. As shown by Eurostat [17], Poland has one of the lowest gross domestic products (GDP) per capita at purchasing power parity (63) among the 27 member states of the European Union, although the pace of economic and social changes has significantly increased over the last 20 years. Concurrently, larger disproportions between different social groups, particularly in small villages, have become evident.

Comparison of the previous and current results in terms of living standards in both periods implies that there is no simple relationship between the socioeconomic status of population and prevalence of pediculosis. Obviously, higher standards of living (higher income, low unemployment rates, better access to water) offer better sanitary security and hygiene and medical care, which is particularly evident in the case of various infectious diseases caused or transmitted by arthropods $[4,12,15,18,19,20]$.

The authors believe that a variety of interacting factors, which should be taken into account in a given study environment, can contribute to pediculosis prevalence and maintenance in an area. Yet, such factors as personal hygiene behaviour, the level of medical care offered to children in school and family, and education of society in the scope of pediculosis epidemiology, play a fundamental role in the spread of head lice. As shown in the presented study, frequent checks of children's heads for the presence of nits and active louse stages (nymphs and adults) reduced the spread of the parasite among schoolchildren in the Lublin macroregion. The regular control of children's hygienic status is indispensable in the case of pediculosis, since head lice, i.e. the agents of the disease, spread rapidly in children's groups through both direct physical contact between a healthy and infested person, and by using combs, hairbrushes, or headgear belonging to an infested person. The high importance of the level of personal hygiene in the spread of pediculosis is supported by the fact that the disease is more frequently diagnosed in children from dysfunctional families, orphanages and special schools, as observed in previous and the current study [4] and by other authors $[21,22]$ in their studies of pediculosis and other infectious diseases, e.g. scabies, which spread through direct contact [18].

Pediculosis was frequently diagnosed among refugees [8, 23 and children living in poor regions $[4,7]$. In turn, lice infestation rates were lower in two-parent families with both parents working [15] and in families with few children [24]. Pediculosis usually affects children aged 3-12, who need adults' care $[2,4,12,13,21,24]$.

Although this study did not focus on the seasonality of pediculosis incidence, infestation cases were more frequently reported after days off from classes, i.e. upon return from short and long holidays. Insufficient parental care, combined with people's high activity and migration during the holiday season, can promote the spread of head lice.

As in other regions [7, 9, 13, 22, 24, 25], in eastern Poland pediculosis was more often diagnosed in girls. However, in the rural schools, the differences in the number of pediculosis cases between girls and boys were lower than in the urban schools. This phenomenon may be explained by the differences in the behaviour of children in these two environments, e.g. their greater integration in villages contributing to transmission of head lice. The higher incidence of head lice in girls than in boys can be explained by the greater length of girls' hair, which offers the arthropod more favourable living conditions, and by girls' lifestyle, e.g. maintaining social contacts $[2,4,14]$.

As shown in the current study, school education concerning infectious diseases transmitted through direct contact is very poor. Campaigns disseminating knowledge about the spread of lice and clinical symptoms of pediculosis, as well as prophylaxis and disease treatment principles, were initiated in a few schools only after the appearance of many pediculosis cases. Introduction of issues related to environmental threats of parasite infections and to prevention methods into school curricula is fully justified, given the fact that pediculosis is more common among children devoid of parental care and adequate hygiene standard [4, 20, 23].

Investigations conducted in different environments have shown that not only access to and use of water [4] is important for maintaining personal hygiene, which reduces the prevalence of pediculosis, but also hygienic habits, especially the frequency of hair washing $[12,16]$.

The increase in lice infestation rates reported worldwide [e.g. 2, 10] can be explained by several factors, the most important of which is increased migration flows and emigrant populations, changes in lifestyle and customs, and increasing resistance of lice to applied insecticides [e.g. 2, 6]. The latter factor is common in developed countries, where chemical lice control agents are used.

The prevalence of head pediculosis in schoolchildren and long-term maintenance of disease foci in some environments suggest that special attention should be paid to this problem by medical and sanitary services and employees of educational institutions. They also highlight the need for more extensive medical care in children, particularly in small and poor communities.

\section{REFERENCES}

1. Falagas ME, Mattaiou DK, Rafailidis PI, Panos G, Pappas G. Worldwide prevalence of head lice. Emerg Infect Dis. 2008; 14(9): 1493-1494.

2. Ko Ch J, Elston DM. Pediculosis. J Am Acad Dermatol. 2004; 50(1): 1-12.

3. Fernández S, Fernández A, Armentia A, Pineda F. Allergy due to head lice (Pediculus humanus capitis). Allergy 2006; 61(11): 1372.

4. Buczek A, Markowska-Gosik D, Widomska D, Kawa IM. Pediculosis capitis among schoolchildren in urban and rural areas of eastern Poland. Eur J Epidemiol. 2004; 19(5): 491-495. 
5. Central Statistical Office Resources, http://www.stat.gov.pl/gus/index_ PLK_HTML.htm. (access 2013.10.08)

6. Durand R, Millard B, Bouges-Michel C, Bruel C, Bouvresse S, Izri A. Detection of pyrethroid resistance gene in head lice in schoolchildren from Bobigny, France. J Med Entomol. 2007; 44(5): 796-798.

7. Willems S, Lapeere H, Haedens N, Pasteels I, Naeyaert J-M, De Maeseneer J. The importance of socio-economic status and individual characteristics on the prevalence of head lice in schoolchildren. Eur J Dermatol. 2005; 15(5): 387-392.

8. Manjrekar RR, Partridge SK, Korman AK, Barwick RS, Juranek DD. Efficacy of $1 \%$ permethrin for the treatment of head louse infestations among Kosovar refugees. Mil Med. 2000; 165(9): 698-700.

9. Bugayong AMS, Araneta KTS, Cabanilla JC, Gayatgay CEU, Nufuar EJT, Rufino KHS, Caro MAC, Padilla PI. Effect of dry-on, suffocationbased treatment on the prevalence of pediculosis among schoolchildren in Calagtangan Village, Miag-ao, Iloilo. Philipp Sci Lett. 2011; 1(4): 33-37.

10. Chouela L, Abeldano A, Cirigliano M, Ducard M, Neglia V, Forgia ML, Colombo A. Head louse infestations: epidemiologic survey and treatment evaluation in Argentinian schoolchildren. Int J Dermatol. 1997; 36(11): 819-825.

11. Morsy TA, el-Ela RG, Morsy AT, Nassar MM, KhalafSA. Two contagious ectoparasites in an orphanage children in Nasr City, Cairo. J Egypt Soc Parasitol. 2000; 30(3): 727-734.

12. Manrique-Saide P, Pavía-Ruz N, Rodríguez-Buenfil JC, Herrera Herrera R, Gómez-Ruiz P, Pilger D. Prevalence of pediculosis capitis in children from a rural school in Yucatan, Mexico. Rev Inst Med Trop Sao Paulo. 2011; 56(6): 325-327.

13. Toloza A, Vassena C, Gallardo A, Gonzáles-Audino P, Picollo MI. Epidemiology of Pediculosis capitis in elementary schools of Buenos Aires, Argentina. Parasitol Res. 2009; 104(6): 1295-1298.

14. Arm ZS, Nusier MN. Pediculosis capitis in northern Jordan. Int Dermatol. 2000; 39(12): 919-921.
15. Sim S, Lee WJ, Yu JR, Lee IY, Lee SH, Oh SY, Seo M, Chai JY. Risk factors associated with head louse infestation in Korea. Korean J Parasitol. 2011; 49(1): 95-98.

16. Yuosefi S, Shamsipoor F, Abadi YS. Epidemiological Study of Head Louse (Pediculus humanus capitis) Infestation Among Primary School Students in Rural Areas of Sirjan County, South of Iran. Thrita J Med Sci. 2012; 1(2): 53-56.

17. European Commission. Eurostat, http://epp.eurostat.ec.europa.eu/ portal/page/portal/eurostat/home (access 2013.10.08).

18. Buczek A, Pabis B, Bartosik K, Stanislawek IM, Salata M, Pabis A. Epidemiological study of scabies in different environmental conditions in central Poland. Ann Epidemiol. 2006; 16(6): 423-428.

19. Bartosik K, Lachowska-Kotowska P, Szymańska J, Pabis A, Buczek A. Lyme borreliosis in south-eastern Poland: relationships with environmental factors and medical attention standards. Ann Agric Environ Med. 2011; 18(1): 131-137.

20. Heukelbach J, Mazigo HD, Ugbomoiko US. Impact of scabies in resource-poor communities. Curr Opin Infect Dis. 2013; 26(2): 127-132.

21. Lonc E, Okulewicz A. Scabies and head-lice infestations in different environmental conditions of Lower Silesia, Poland. J Parasitol. 2000; 86(1): 170-171.

22. Gliniewicz A, Sawicka B, Kędra E, Wieloch W. Head pediculosis in children's homes in Warsaw and Mazowieckie Province in the years 2007-2008: its occurrence and control. In: Buczek A, Błaszak C (eds.). Arthropods. Invasions and their control, Lublin 2009.p.233-41.

23. Mumcuoglu KY, Miller J, Manor O, Ben-Yshai F, Klaus S. The prevalence of ectoparasites in Ethiopian immigrants. Isr J Med Sci. 1993; 29(6-7): 371-373.

24. Wegner Z, Racewicz M, Stańczak J. Occurrence of pediculosis capitis in a population of children from Gdańsk, Sopot, Gdynia and the vicinities. Appl Parasitol. 1994; 35(3): 219-225.

25. Piotrowski F. Head pediculosis among children and youth in Gdańskie Province in 1979. Wiad Parazytol. 1982; 28(2-3):133-137 (In Polish). 